\title{
Carapace width-weight relationships and condition factor of blue swimming crab, Portunus pelagicus Linnaeus, 1758 (Crustacea: Decapoda) in Lasongko Bay, Southeast Sulawesi, Indonesia
}

\author{
Abdul Hamid', Djamar TF Lumban Batu², Etty Riani² ${ }^{2}$ and Yusli Wardiatno ${ }^{2 *}$ \\ ${ }^{1}$ Department of Aquatic Resources Management, Faculty of Fisheries and Marine Sciences, Halu Oleo University, Kampus Hijau Bumi Tridharma Anduonohu \\ Kendari 93232, Indonesia \\ ${ }^{2}$ Department of Aquatic Resources Management, Faculty of Fisheries and Marine Science, Bogor Agricultural University, Jalan Raya Darmaga, Kampus IPB, \\ Bogor 16680, West Java, Indonesia
}

Correspondence Author: Yusli Wardiatno, Department of Aquatic Resources Management, Faculty of Fisheries and Marine Science, Bogor Agricultural University, Jalan Raya Darmaga, Kampus IPB, Bogor 16680, West Java, Indonesia

Received date: 12 August 2018, Accepted date: 10 November 2018, Online date: 25 November 2018

Copyright: (C) 2018 Abdul Hamid et al., This is an open-access article distributed under the terms of the Creative Commons Attribution License, which permits unrestricted use, distribution, and reproduction in any medium, provided the original author and source are credited.

\begin{abstract}
To date, studies of carapace width-weight relationships in blue swimming crab (Portunus pelagicus Linnaeus, 1758) have primarily focused on differences between males and females within a population, whereas studies of the condition factor of this species remain limited. The objective of this study is to assess the carapace width-weight relationships and the condition factor of juvenile and adult crabs throughout the season in Lasongko Bay, Southeast Sulawesi, Indonesia. Monthly samplings of crabs were conducted using gill nets from April 2013 until March 2014. Data were analyzed by sex (juvenile and adult) and season. Carapace width-weight relationships were expressed as power and linear equations. Parameter values of the equations and the growth coefficient were tested using ANCOVA and $t$-tests, respectively; the condition factor was analysed descriptively. Carapace width-weight relationships of male and female juveniles and adults as well as ovigerous females exhibited very strong and positive relationships and an ismoteric pattern of growth. The growth coefficient and condition factor in both sexes fluctuated throughout the study period. Monthly fluctuations in the condition factor of male and female crabs were within similar ranges. Temporal variation in the fluctuations and timing of peak values of $b$ and the conditions factor of male and female crabs was likely related to the crab reproductive cycle, particularly peak spawning in Lasongko Bay.
\end{abstract}

Key words: Allometric relationships, BSC fishery, growth pattern, Portunidae

\section{INTRODUCTION}

Blue swimming crab (Portunus pelagicus Linnaeus, 1758) is one of the most economically important crab species due to high commercial demand. The distribution of this species is concentrated in Southeast Asian waters in a variety of habitats, i.e. from intertidal areas to depths of $65 \mathrm{~m}$, in benthic areas covered by seagrass and algae, or even along a stretch of beach in substrates of mud, clay, or sand [5,6,14,19,22,25,44].

The growth of crustaceans, including crabs, often involves several changes in the dimensions of one part of the body, which is typically referred to as relative growth $[2,18,21]$. Relative growth in crustaceans can be expressed by two morphometric trait relationships, with carapace width or length generally fixed as the independent variable $[2,18,26,34,43]$. Carapace width or length is also widely used to illustrate relationships between crab size and egg number in reproductive studies of crustaceans $[8,14-16,45]$. In allometric studies, the relationships between these two variables are usually expressed as power and linear equations $[2,21,26,40]$.

In ecological studies of crabs, carapace width-weight relationships can be converted to a weight growth regression equation, which is useful for estimating the stock population size, particularly for exploitation purposes [3,21]. Carapace width-weight relationships of crabs have been considered more suitable for evaluating crab population sizes compared to relationships between other crab morphometric characters [21]. Moreover, carapace width-weight relationships can be used in ecological studies to estimate the condition factor as a quantitative indicator of the 'well-being' of a species in its environment [2]. The condition factor of crabs may be influenced by environmental factors, gonadal development, growth, food availability, and parasitic conditions, and these factors often vary among seasons, populations [2,26], and rates of exploitation [10].

Numerous studies have assessed carapace width-weight relationships of blue swimming crabs [1, 6,20,21,23,24,31,37,38,40,41]. Nearly all of the published research has focused on male-female carapace width-weight relationships, whereas stage-based studies (i.e. juveniles versus adults) as well as seasonal studies are lacking, particularly in Indonesian waters. Several studies have examined the condition factor of crabs [4,31,32,41], but results have been variable. Lasongko Bay is a centre of the blue swimming crab fishery in Province of Southeast Sulawesi, Indonesia. Biological information such as habitat-based distribution and reproductive aspects has been collected previously for $P$. pelagicus in the region $[12,14-16]$, reproductive aspects [12,15,16], etc. The objective of the present study is to assess the carapace width-weight relationships and the condition factor of male and female $P$. pelagicus at the juvenile and adult stages throughout the season in Lasongko Bay. Our findings will be beneficial for the sustainable management of the blue swimming crab in the bay. 


\section{Research Location}

\section{MATERIAL AND METHODS}

This study was conducted in Lasongko Bay, Southeast Sulawesi $\left(05^{\circ} 15^{\prime}-05^{\circ} 27^{\prime} \mathrm{S}, 122^{\circ} 27^{\prime}-122^{\circ} 33^{\prime}\right.$ E; Fig. 1). Monthly samples were collected from April 2013 to March 2014 in an area of about $13.6 \mathrm{~km}^{2}$. Sampling period was grouped into two seasons, i.e. East Season (April - September 2013 ) and West Season (October 2013 - March 2014)

\section{Sampling and Measurement Procedures}

Crabs were collected from seven sampling stations ranging from the inner to the outer area of the bay (see Fig. 1). Monthly samples were collected using bottom gill nets with mesh sizes of $1.5,2.5$, and 3.5 inches. Gill nets were set out in the late afternoon, and the entangled crabs were collected during the morning of the next day.

In the laboratory, individuals of $P$. pelagicus were first classified as male or female, and carapace widths (CW) were measured using callipers (Vernier Caliper 0-150 $\mathrm{mm} \times 0.05$ ) with an accuracy of $0.01 \mathrm{~mm}$. Body weight was measured using a digital balance (Xon Med Digital Scale) with an accuracy of $0.01 \mathrm{~g}$. Male and female crabs were also classified as juveniles $(\mathrm{CW}<87.00 \mathrm{~mm})$, adults $(\mathrm{CW}>87 \mathrm{~mm})$ and ovigerous females. Carapace width-weight relationships of the crabs were determined using an allometric growth equation in the form of the following power equation $[6,21,23,38]$ :

$\mathrm{BW}=\mathrm{aCW}^{\mathrm{b}}$

where BW is body weight $(\mathrm{g}), \mathrm{CW}$ is carapace width $(\mathrm{mm})$, a is the intercept and $\mathrm{b}$ is the crab growth coefficient. To simplify calculations, equation (1) was transformed to $\log _{10}$ to obtain a linear equation as follows:

$\log (\mathrm{BW})=\log (\mathrm{a})+\mathrm{b} \log (\mathrm{CW})$

...(2)

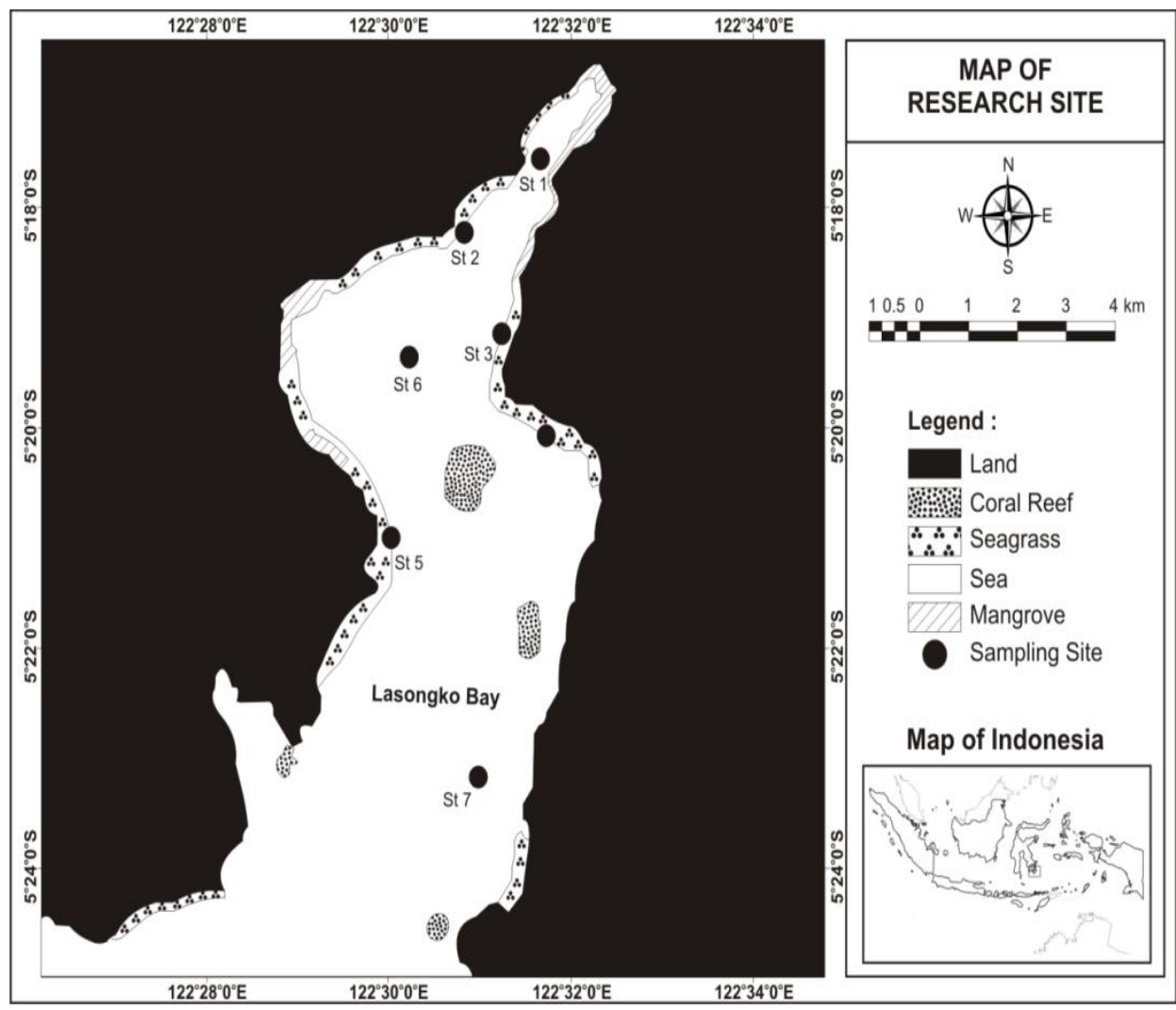

Fig. 1: Location of the study site in Lasongko Bay, Central Buton, Indonesia. Black dots indicate sampling sites (adapted from Hamid et al. [15]). The condition factor $(\mathrm{K})$ for each sex was determined using the following equation $[3,11]$ :

$\mathrm{K}=100 \times \mathrm{BW}_{\mathrm{m}} /\left(\mathrm{CW}_{\mathrm{m}}\right)^{3}$

where $\mathrm{BW}_{\mathrm{m}}$ is the mean body weight $(\mathrm{g})$, and $\mathrm{CW}_{\mathrm{m}}$ is the mean carapace width $(\mathrm{mm})$.

Data analysis

Analysis of covariance (ANCOVA) was used to test the significance of the regression coefficient "b" and intercept "a" of the carapace width-weight relationships [42]. The allometric growth pattern of the carapace width-weight relationships was determined based on the value of " $\mathrm{b}$ " using $t$-tests at $\mathrm{p}=0.05$ [42]. Allometric growth was categorised as follows: isometric if $b=3$, negative allometric if $b<3$, and positive allometric if $b>3$ [18,21,40].

\section{RESULTS}

\section{Carapace Width-Weight Relationships}

In general, the growth coefficient (b) of the carapace width-weight relationships in males ranged from 3.065 to 3.151 , while the value in females ranged from 2.168 to 2.961 (Table 1 and Fig. 2). The values of $b$ for juveniles and adult males were relatively similar, whereas in females, the values for juveniles were lower than those of adults and ovigerous females.

The correlation coefficients ( $r$ ) of the carapace width-weight relationships in male crabs (juveniles, adults, and both combined ranged from 0.903 to 0.942 , while those in females ranged from 0.705 to 0.942 . Values of $r$ for juveniles were higher than those of adult males but not in adult females. 
Citation: Abdul Hamid, Djamar TF Lumban Batu, Etty Riani, Yusli Wardiatno, 2018. Carapace width-weight relationships and condition factor of blue swimming crab, Portunus pelagicus Linnaeus, 1758 (Crustacea: Decapoda) in Lasongko Bay, Southeast Sulawesi, Indonesia. Advances in Environmental Biology. 12(11): 14-21.DOI:10.22587/aeb.2018.12.11.2

Table 1: Carapace width-weight relationships, correlation coefficient (r), ANCOVA, t-test value b, and allometric growth pattern (Al) of male (juvenile and adult) and female (juvenile, adult and ovigerous) crabs Portunus pelagicus of Lasongko Bay, Southeast Sulawesi - Indonesia with linear equation.

\begin{tabular}{|c|c|c|c|c|c|c|}
\hline \multirow[t]{2}{*}{ Sex } & \multirow[t]{2}{*}{ Linear equation } & \multirow[t]{2}{*}{$\mathrm{r}$} & \multicolumn{2}{|c|}{ ANCOVA } & \multirow{2}{*}{$\begin{array}{c}\text { t-test } \\
b=3\end{array}$} & \multirow[t]{2}{*}{$\mathrm{Al}$} \\
\hline & & & $\mathrm{a}$ & $\mathrm{b}$ & & \\
\hline \multicolumn{7}{|l|}{ Male: } \\
\hline Juvenile & $\log B W=-4.457+3.150 \log C W$ & 0.913 & $-12.751 * *$ & $17.181 * *$ & $-0.115^{\mathrm{ns}}$ & 0 \\
\hline Adult & $\log B W=-4.487+3.151 \log C W$ & 0.903 & $-34.140 * *$ & $48.985^{* *}$ & $-0.117^{\mathrm{ns}}$ & 0 \\
\hline Total & $\log B W=-4.309+3.065 \log C W$ & 0.942 & $-46.207 * *$ & $66.702 * *$ & $-0.050^{\mathrm{ns}}$ & 0 \\
\hline \multicolumn{7}{|l|}{ Female: } \\
\hline Juvenile & $\log \mathrm{BW}=-2.599+2.168 \log \mathrm{CW}$ & 0.705 & $-4.525 * *$ & $7.176^{* *}$ & $0.690^{\mathrm{ns}}$ & 0 \\
\hline Adult & $\log B W=-4.112+2.961 \log C W$ & 0.942 & $-42.004 * *$ & $61.912 * *$ & $0.031^{\mathrm{ns}}$ & 0 \\
\hline Ovigerous & $\log \mathrm{BW}=-0.957+2.837 \log \mathrm{CW}$ & 0.895 & $-8.322 * *$ & $26.433^{* *}$ & $-0.291^{\mathrm{ns}}$ & 0 \\
\hline Total & $\log B W=-3.979+2.903 \log C W$ & 0.942 & $-47.689 * *$ & $71.008^{* *}$ & $-0.025^{\mathrm{ns}}$ & 0 \\
\hline
\end{tabular}

**: Highly significant $(\mathrm{p}<0.001)$, ns: not significant $(\mathrm{p}>0.05), 0$ : isometric.

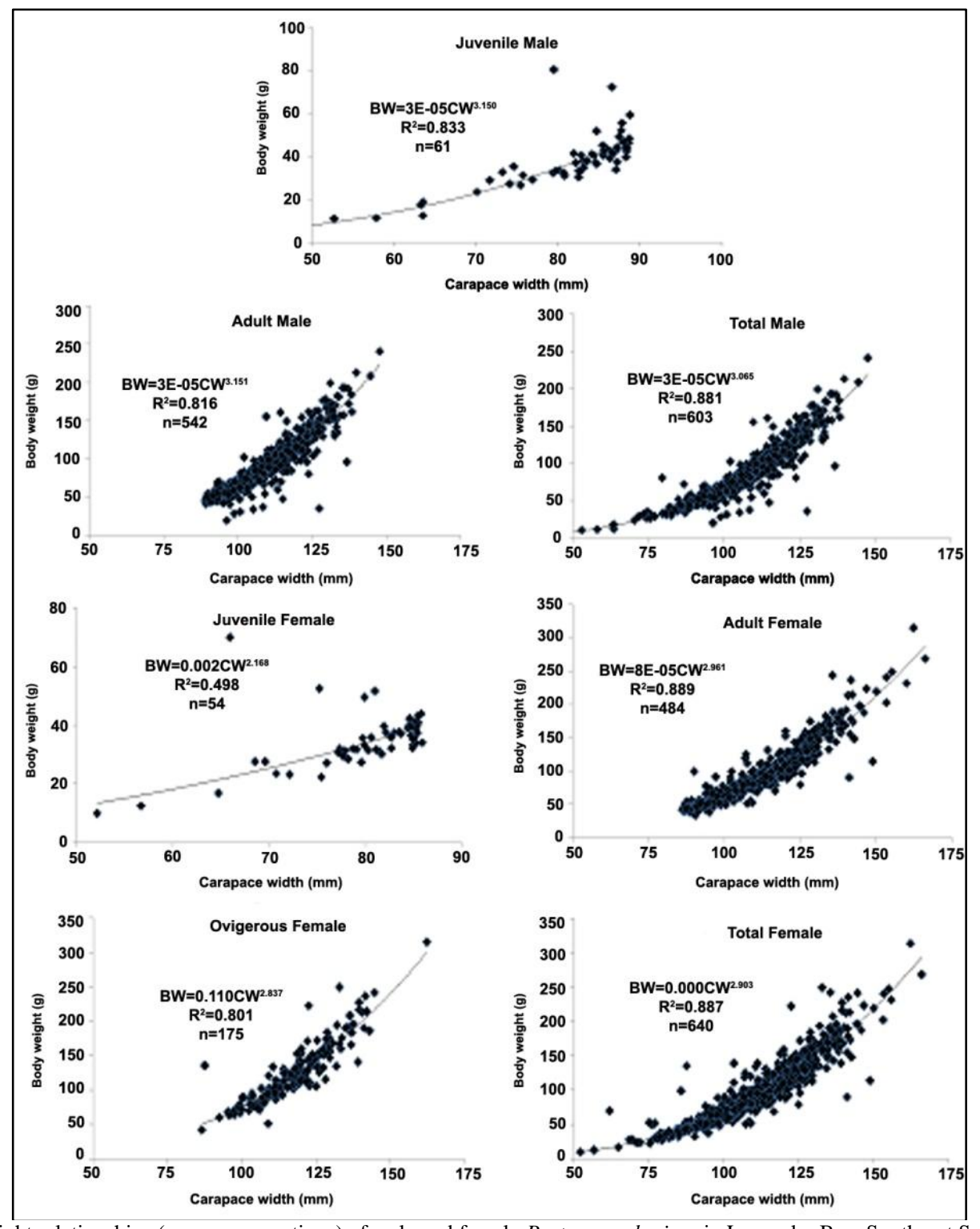

Fig. 2: Carapace width-weight relationships (as power equations) of male and female Portunus pelagicus in Lasongko Bay, Southeast Sulawesi, Indonesia ANCOVA results for values of $\mathrm{a}$ and $\mathrm{b}$ in the carapace width-weight relationships of male and female juveniles and adults and ovigerous females were highly significant $(\mathrm{p}<0.001)$, with strong, positive correlation coefficients $(r)$. Values of $b$ did not significantly differ $(t$-test, $p<0.05$ ) from 3 (Table 2 ) for the juvenile and adult stages of both sexes as well as ovigerous females; therefore, the growth patterns for all categories were isometric. 
Citation: Abdul Hamid, Djamar TF Lumban Batu, Etty Riani, Yusli Wardiatno, 2018. Carapace width-weight relationships and condition factor of blue swimming crab, Portunus pelagicus Linnaeus, 1758 (Crustacea: Decapoda) in Lasongko Bay, Southeast Sulawesi, Indonesia. Advances in Environmental Biology. 12(11): 14-21.DOI:10.22587/aeb.2018.12.11.2

Table 2: Carapace width-weight relationships, correlation coefficient (r) and type of allometric growth (Al) of male and female Portunus pelagicus of Lasongko Bay, Southeast Sulawesi - Indonesia at each season and month with power equation.

\begin{tabular}{|c|c|c|c|c|c|c|c|c|}
\hline \multirow[t]{2}{*}{ Season- Month } & \multicolumn{4}{|c|}{ Male } & \multicolumn{4}{|c|}{ Female } \\
\hline & $\mathrm{n}$ & Power & $\mathrm{r}$ & $\left.\mathrm{Al}^{*}\right)$ & $\mathrm{N}$ & Power & $\mathrm{r}$ & $\left.\mathrm{Al}^{*}\right)$ \\
\hline East season & 311 & $\mathrm{BW}=9 \mathrm{E}-05 \mathrm{CW}^{2.947}$ & 0.912 & & 332 & $\mathrm{BW}=0.000 \mathrm{CW}^{2.824}$ & 0.964 & \\
\hline April-13 & 62 & $\mathrm{BW}=0.084 \mathrm{CW}^{2.860}$ & 0.815 & 0 & 56 & $\mathrm{BW}=0.140 \mathrm{CW}^{2.214}$ & 0.824 & - \\
\hline May-13 & 99 & $\mathrm{BW}=0.087 \mathrm{CW}^{2.896}$ & 0.964 & 0 & 89 & $\mathrm{BW}=0.085 \mathrm{CW}^{2.889}$ & 0.973 & 0 \\
\hline June-13 & 54 & $\mathrm{BW}=0.049 \mathrm{CW}^{3.130}$ & 0.961 & 0 & 58 & $\mathrm{BW}=0.085 \mathrm{CW}^{2.888}$ & 0.914 & 0 \\
\hline July-13 & 44 & $\mathrm{BW}=0.053 \mathrm{CW}^{3.074}$ & 0.920 & 0 & 52 & $\mathrm{BW}=0.097 \mathrm{CW}^{2.846}$ & 0.902 & 0 \\
\hline August-13 & 33 & $\mathrm{BW}=0.144 \mathrm{CW}^{2.692}$ & 0.874 & - & 42 & $\mathrm{BW}=0.049 \mathrm{CW}^{3.134}$ & 0.978 & 0 \\
\hline September-13 & 20 & $\mathrm{BW}=0.084 \mathrm{CW}^{2.907}$ & 0.942 & 0 & 36 & $\mathrm{BW}=0.110 \mathrm{CW}^{2.808}$ & 0.897 & 0 \\
\hline West season & 292 & $\mathrm{BW}=3 \mathrm{E}-05 \mathrm{CW}^{3.159}$ & 0.964 & & 328 & $\mathrm{BW}=3 \mathrm{E}-05 \mathrm{CW}^{3.134}$ & 0.959 & 0 \\
\hline October-13 & 37 & $\mathrm{BW}=0.077 \mathrm{CW}^{2.960}$ & 0.876 & 0 & 48 & $\mathrm{BW}=0.077 \mathrm{CW}^{2.946}$ & 0.897 & 0 \\
\hline November-13 & 26 & $\mathrm{BW}=0.042 \mathrm{CW}^{3.187}$ & 0.871 & 0 & 44 & $\mathrm{BW}=0.104 \mathrm{WC}^{2.816}$ & 0.924 & 0 \\
\hline December-13 & 53 & $\mathrm{BW}=0.041 \mathrm{CW}^{3.198}$ & 0.966 & 0 & 52 & $\mathrm{BW}=0.039 \mathrm{CW}^{3.198}$ & 0.959 & 0 \\
\hline January-14 & 80 & $\mathrm{BW}=0.050 \mathrm{CW}^{3.109}$ & 0.984 & 0 & 76 & $\mathrm{BW}=0.027 \mathrm{CW}^{3.350}$ & 0.970 & + \\
\hline February-14 & 49 & $\mathrm{BW}=0.049 \mathrm{CW}^{3.131}$ & 0.981 & 0 & 54 & $\mathrm{BW}=0.056 \mathrm{CW}^{3.054}$ & 0.964 & 0 \\
\hline March-14 & 47 & $\mathrm{BW}=0.041 \mathrm{CW}^{3.202}$ & 0.965 & 0 & 53 & $\mathrm{BW}=3.054 \mathrm{CW}^{3,065}$ & 0.977 & 0 \\
\hline
\end{tabular}

*) Results $\mathrm{t}$ test of $\mathrm{b}=3(\mathrm{p}<0.05), 0$ isometric - negative allometric, + allometric positif, $\mathrm{n}$ samples number

Results of ANCOVA analysis of a and $b$ male and female were all highly significant $(\mathrm{p}<0.001)$

Values of $\mathrm{b}$ of for the carapace width-weight relationships in males during the East and West Seasons were 2.947 and 3.159, respectively, and monthly values ranged from 2.692 to 3.198, with a maximum in December and minimum in August. Monthly values of $\mathrm{r}$ for the carapace width-weight relationships of male crabs ranged from 0.815 to 0.961 (Table 2). Values of b for the carapace width-weight relationships of female crabs during the East and West Seasons seasons ranged from 2.824 to 3.134 , and monthly values ranged from 2.214 to 3.350 , with values of $r$ from 0.824 to 0.978 . Values of $b$ for the carapace width-weight relationships of female crabs were highest in January and lowest in April. In general, the values of b for male and female crabs during the East Season tended to fluctuate more than during the West Season (Fig. 3).

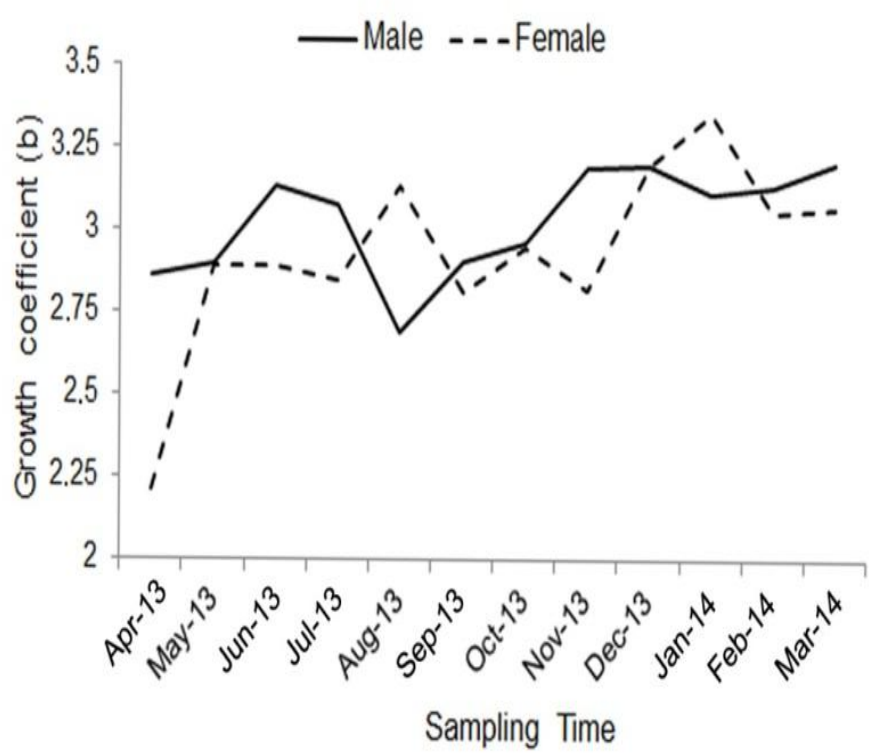

Fig. 3: Monthly values of $\mathrm{b}$ for the carapace width-weight relationships of male and female Portunus pelagicus in Lasongko Bay, Southeast Sulawesi, Indonesia. The carapace width-weight relationships of male crabs during the East and West Seasons and during each month exhibited highly significant positive relationships $(\mathrm{p}<0.001)$. Most values of $\mathrm{b}$ for male and female crabs during each month and season did not significantly differ $(t$-test, $\mathrm{p}>0.05)$ from $\mathrm{b}=3$, except for male crabs in August and for female crabs in April and January. Therefore, the type of allometric growth for male and female crabs during each season and month was primarily isometric, except for male crabs in August and female crabs in April (negative allometric) and female crabs in January (positive allometric).

\section{Condition Factor}

The values of the condition factor of juvenile and adult male crabs were $71.18 \times 10^{-4}$ and $69.99 \times 10^{-4}$, respectively, and those for juvenile, adult, and ovigerous females were $68.68 \times 10^{-4}, 67.72 \times 10^{-4}$, and $76.66 \times 10^{-4}$, respectively (Table 3). The condition factor of male crabs during the East Season was lower than during the West Season, while the opposite was true of female crabs (Table 4). 
Citation: Abdul Hamid, Djamar TF Lumban Batu, Etty Riani, Yusli Wardiatno, 2018. Carapace width-weight relationships and condition factor of blue swimming crab, Portunus pelagicus Linnaeus, 1758 (Crustacea: Decapoda) in Lasongko Bay, Southeast Sulawesi, Indonesia. Advances in Environmental Biology. 12(11): 14-21.DOI:10.22587/aeb.2018.12.11.2

Table 3: Carapace width, weight, condition factor of juvenile and adult male and female as well as ovigerous female of Portunus pelagicus of Lasongko Bay, Southeast Sulawesi - Indonesia.

\begin{tabular}{|c|c|c|c|}
\hline Sex & $\mathrm{n}$ & Carapace width $(\mathrm{mm})$ & Body weigth (g) \\
\hline Male: & & & \\
\hline Juvenile & 61 & $110.87 \pm 11.99$ & $37.85 \pm 12.84$ \\
\hline Adult & 542 & $107.85 \pm 14.78$ & $95.40 \pm 35.40$ \\
\hline Total & 603 & & $89.57 \pm 38.00$ \\
\hline Female: & 54 & $79.60 \pm 7.20$ & $34.64 \pm 9.39$ \\
\hline Juvenile & 484 & $112.60 \pm 15.13$ & $96.69 \pm 42.54$ \\
\hline Adult & 174 & $118.25 \pm 12.12$ & $126.75 \pm 42.28$ \\
\hline Ovigerous & 639 & $110.91 \pm 17.28$ & $98.68 \times 10^{-4}$ \\
\hline Total & & $67.72 \times 10^{-4}$ & \\
\hline
\end{tabular}

Table 4: Carapace width (CW) and condition factor of male and female Portunus pelagicus of Lasongko Bay, Southeast Sulawesi - Indonesia according to season.

\begin{tabular}{|c|c|c|c|c|c|c|}
\hline \multirow{2}{*}{ Sex } & \multicolumn{3}{|c|}{ East season } & \multicolumn{4}{|c|}{ West season } \\
\cline { 2 - 7 } & $\mathrm{n}$ & $\mathrm{CW}(\mathrm{mm})$ & Condition factor & $\mathrm{n}$ & $\mathrm{CW}(\mathrm{mm})$ & Condition factor \\
\hline Male & 311 & $106.35+13.67$ & $70.49 \times 10^{-4}$ & 292 & $109.50 \pm 15,73$ & $72.34 \times 10^{-4}$ \\
\hline Female & 292 & $107.37 \pm 16.16$ & $71.55 \times 10^{-4}$ & 328 & $114.82 \pm 17,22$ & $70.58 \times 10^{-4}$ \\
\hline
\end{tabular}

Monthly values of the condition factor of male crabs ranged from $65.08 \times 10^{-4}$ to $74.64 \times 10^{4}$, with a (mean \pm SE) of $\left(71.30 \times 10^{-4} \pm 2.40 \times 10^{-4}\right)$ and a maximum in February and minimum in April. Monthly values of the condition factor of female crabs ranged from $68.66 \times 10^{-4}$ to $73.51 \times 10^{-4}$, with a (mean \pm SE) of $\left(70.91 \times 10^{-4}\right.$ $\pm 1.58 \times 10^{-4}$ ) and a maximum in August and minimum in April (Fig. 4)

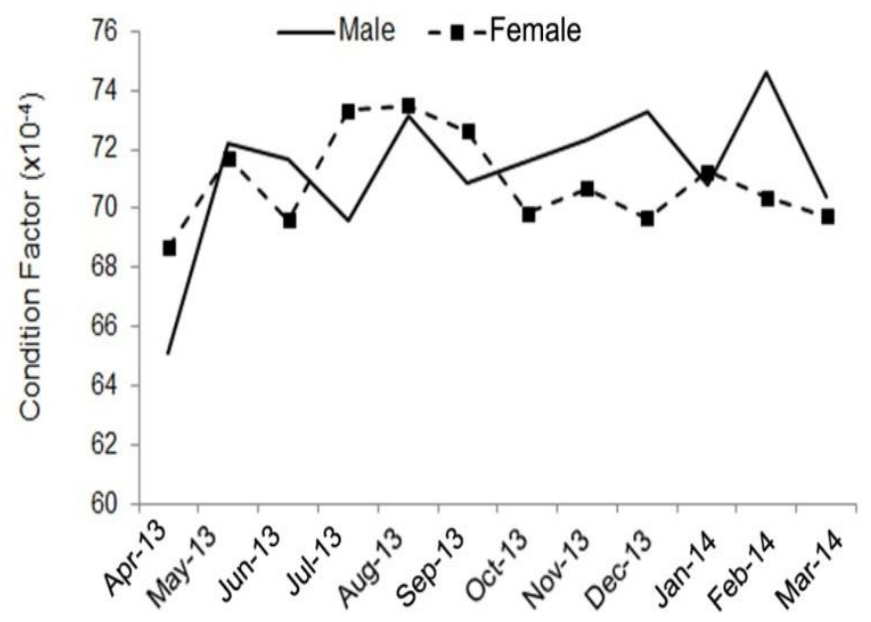

Sampling Time

Fig. 4: Monthly values of the condition factors of male and female Portunus pelagicus in Lasongko Bay, Southeast Sulawesi, Indonesia.

\section{DISCUSSION}

\section{Carapace Width-Weight Relationships}

In general, the values of $\mathrm{b}$ in the carapace width-weight relationships of male crabs were larger than values for female crabs, indicating that the growth of male crabs in terms of weight was faster than that of female crabs. All values of $b$ for juvenile, adult, and composite male crabs were greater than 3 , whereas all values for female crabs and ovigerous females were less than 3 . However, the values of $\mathrm{b}$ for both sexes and all categories of crabs did not differ significantly ( $t$ test, $\mathrm{p}>0.05$ ) from 3. Therefore, the growth of both sexes of $P$. pelagicus was isometric, i.e. growth by weight was balanced by the (cubic) growth of carapace width. The values of $\mathrm{b}$ and $\mathrm{r}$ for the carapace width-weight relationships of male and female crabs in Lasongko Bay are limited to specific ranges in both Indonesia and other areas around the world (Table 5). The values of b and $\mathrm{r}$ for male crabs from other areas ranged from 2.7542 to 3.6167 and from 0.860 to 0.9936 , respectively, while those for females ranged from 2.6508 to 3.299 and from 0.817 to 0.9961 , respectively. Relationships for both sexes varied geographically. The observed isometric growth pattern for both sexes of crabs in Lasongko Bay was similar to those observed along the Karachi coast of Pakistan [35] and the Oman coast for females [27], whereas both positive and negative allometric growth have been observed in other areas (Table 5). The type of allometric growth of male and female crabs in Lasongko Bay did not differ between the juvenile and adult stages, whereas the rate of growth by the weight and by the carapace width changed. The growth rate by weight of male crabs did not differ between juveniles and adults. In contrast, the growth rate by weight of juvenile female crabs was slower than for adult females. The growth rate by weight of ovigerous female crabs was also slower than that for non-ovigerous adult females.

The type of growth by the weight and by the carapace width in juvenile and adult male and female crabs in Lasongko Bay differs from those observed along the northwest coast of Karnataka, India. Juvenile male and female crabs in Karnataka exhibited negative allometric growth by weight, whereas that of adults was 
Citation: Abdul Hamid, Djamar TF Lumban Batu, Etty Riani, Yusli Wardiatno, 2018. Carapace width-weight relationships and condition factor of blue swimming crab, Portunus pelagicus Linnaeus, 1758 (Crustacea: Decapoda) in Lasongko Bay, Southeast Sulawesi, Indonesia. Advances in Environmental Biology. 12(11): 14-21.DOI:10.22587/aeb.2018.12.11.2

positive [40]. Differences in the value of $b$ between juvenile and adult crabs (both male and female) may be caused by differences in diet due to stage-based variation in factors such as size, claw strength, foraging behaviour, and metabolic rates [40], as well as by differences in food availability, sex, gonad maturation stage, and season $[10,39]$.

Table 5: Growth coefficient (b), correlation coefficient (r) and type of allometric growth (Al) carapace width-weight of male and female blue swimming crab from some locations.

\begin{tabular}{|c|c|c|c|c|c|}
\hline Location & Sex & $\mathrm{b}$ & $\mathrm{r}$ & $\mathrm{Al}$ & Source \\
\hline \multirow{2}{*}{$\begin{array}{l}\text { Bardawil Lagoon, } \\
\text { North Sinai, Egypt }\end{array}$} & Male & 3.2062 & 0.966 & + & \multirow[t]{2}{*}{36} \\
\hline & Female & 2.9517 & 0.987 & - & \\
\hline \multirow[t]{2}{*}{ Oman Coast, Oman } & Male & 3.2401 & 0,9746 & + & \multirow[t]{2}{*}{27} \\
\hline & Female & 3.0061 & 0,9591 & $\mathrm{O}$ & \\
\hline \multirow[t]{2}{*}{ Persia Gulf \& Oman Bay, Iran } & Male & 3.214 & 0.9758 & + & \multirow[t]{2}{*}{37} \\
\hline & Female & 3.299 & 0.9055 & + & \\
\hline \multirow[t]{2}{*}{ Karnataka Coast, South-west India } & Male & 3.6167 & 0.985 & + & \multirow[t]{2}{*}{40} \\
\hline & Female & 3.2327 & 0.988 & + & \\
\hline \multirow[t]{2}{*}{ Mandapam Coast, Southeast India } & Male & 3.607 & 0.9691 & + & \multirow[t]{2}{*}{21} \\
\hline & Female & 3.293 & 0.9365 & + & \\
\hline \multirow[t]{2}{*}{ Karachi Coast, Pakistan } & Male & 3.0278 & 0.9936 & $\mathrm{O}$ & \multirow[t]{2}{*}{34} \\
\hline & Female & 2.9864 & 0.9961 & $\mathrm{O}$ & \\
\hline \multirow[t]{2}{*}{ Sindh \& Balochistan, Pakistan } & Male & 2.56 & 0.8994 & - & \multirow[t]{2}{*}{1} \\
\hline & Female & 2.95 & 0.9386 & - & \\
\hline \multirow[t]{2}{*}{ Kung Krabaen Bay, Thailand } & Male & 2.9211 & 0.981 & - & \multirow[t]{2}{*}{24} \\
\hline & Female & 2.8944 & 0.967 & - & \\
\hline \multirow[t]{2}{*}{ Batu Itam- East Belitung, Indonesia } & Male & 3.2509 & 0.9424 & + & \multirow[t]{2}{*}{32} \\
\hline & Female & 3.1481 & 0.9325 & + & \\
\hline \multirow[t]{2}{*}{ Pati Waters, Indonesia } & Male & 3.342 & 0.957 & + & \multirow[t]{2}{*}{9} \\
\hline & Female & 3.259 & 0.948 & + & \\
\hline \multirow[t]{2}{*}{ Pangkep Waters, Indonesia } & Male & 2.7542 & 0.860 & - & \multirow[t]{2}{*}{20} \\
\hline & Female & 2.6508 & 0.817 & - & \\
\hline \multirow[t]{2}{*}{ Betahwalang Coast - Demak, Indonesia } & Male & 3.2120 & 0.9473 & + & \multirow[t]{2}{*}{30} \\
\hline & Female & 3.1518 & 0.9417 & + & \\
\hline \multirow[t]{2}{*}{ Lasongko Bay, Indonesia } & Male & 3.065 & 0.942 & $\mathrm{O}$ & \multirow[t]{2}{*}{ This study } \\
\hline & Female & 2.903 & 0.942 & $\mathrm{O}$ & \\
\hline
\end{tabular}

Note: $\mathrm{O}=$ isometric, $-=$ negative allometric, $\quad+=$ positive allometric

The values of $b$ for the carapace width-weight relationships of male and female crabs during the East Season were lower than those during the West season. The values of $\mathrm{b}$ for males and females fluctuated throughout the year (see Fig. 3), with coefficients of variation of monthly values for male and female crabs of 5.37 and $9.61 \%$, respectively. Based on the values of b, three periods of peak growth in body weight can be differentiated for both male and female crabs in Lasongko Bay: peaks for males occurred in June, November-December, and March, while those for females occurred in May, August, and December (see Fig. 4). These results differ from those reported for the carapace width-weight relationships of mud crab (Scylla serrata), for which the values of b tended to vary annually or periodically [29, 39]. Changes in the value of b can be triggered by metamorphosis, moulting, the initial maturation of gonads, and changing environmental conditions [1,39], as well as sizes and length range of samples used, sexual dimorphism, and availability of food (1,28).

\section{Condition Factor}

The condition factor of composite male crabs was lower than that of composite female crabs; crab females contained more fat than did males, and male crabs were smaller than females (Table 3). Higher condition factors in female versus male crabs have also been observed in other crab species, such as Callinectes sapidus [3], C. danae [2], and P. segnis [31]. In contrast, the condition factor was larger in males relative to females in $S$. serrata [29,39]. In the present study, the condition factor of ovigerous female crabs was higher than values for non-ovigerous females and juveniles, likely due to the larger body size of ovigerous females and the fact that incubating eggs increase body weight. The condition factors of male and female juvenile crabs were higher than values for adults.

The condition factors of composite male and female crabs were smaller than those reported in the waters of Brebes, Indonesia [41], the eastern waters of Batu Itam-Belitung, Indonesia [32], several locations in the Persian Gulf [4], as well as those reported for C. danae [2]. In contrast, the conditions factors observed in Lasongko Bay were higher than those for blue swimming crab (P. segnis) in the Bandar Abbas along the Persian Gulf [31] and for $P$. validus along the coast of Lagos, Nigeria [33]. The condition factors of aquatic organisms such as crabs are strongly influenced by food availability, habitat quality, disease, population density, gonad development, growth rate, and over-exploitation [7,10]. The latter factor is particularly important in the over-harvested population of crabs in Lasongko Bay [13,17].

During our study, the condition factors of male and female crabs fluctuated throughout the year, and each sex tended to exhibit four peaks (see Fig. 3). The first two peaks of the condition factor of female crabs were more prominent (in May and July-August), while the peaks in November and January were less pronounced (see Fig. 4). The peaks in the condition factor of male crabs in Lasongko Bay occurred in May, August, December, and February, all of which occurred at relatively the same level. The condition factor of male crabs was more variable than that of females, resulting in a higher coefficient of variation in the condition factor for males $(3.37 \%)$ relative to females $(2.22 \%)$. 
Citation: Abdul Hamid, Djamar TF Lumban Batu, Etty Riani, Yusli Wardiatno, 2018. Carapace width-weight relationships and condition factor of blue swimming crab, Portunus pelagicus Linnaeus, 1758 (Crustacea: Decapoda) in Lasongko Bay, Southeast Sulawesi, Indonesia. Advances in Environmental Biology. 12(11): 14-21.DOI:10.22587/aeb.2018.12.11.2

In Lasongko Bay, the peak period of fluctuation in the condition factor of male and female crabs tended to occur during the same period as peak spawning. These waters experience three peaks in crab spawning: in May-June, August, and October-November [12]. This correspondence between peak fluctuation and peak spawning is consistent with previous reports documenting that variation in the condition factors of crabs occurs throughout the year and is related to the reproductive cycle, particularly during peak periods of spawning [2,31 39].

\section{CONCLUSION}

The carapace width-weight relationships of male and female crabs were strong and significantly positive, both by stage (juveniles and adults) and by season; overall, the type of allometric growth was isometric. The condition factors of juvenile male and female crabs were higher than those of adults but lower than those of ovigerous females. The condition factor of male crabs during the East Season was lower than during the West Season, whereas the opposite pattern occurred in females. Temporal variation in the fluctuations and timing of peak values of $b$ and the conditions factor of male and female crabs was likely related to the crab reproductive cycle, particularly peak spawning in Lasongko Bay. The information obtained in this study is beneficial for crab fishery biologists to estimate the carapace width- weight based on the body crab and for the sustainable management of the blue swimming crab.

\section{ACKNOWLEDGEMENTS}

The authors would like to thank to Kaharudin and La Mpiri for their help in crab collection. The first author thanked to Bogor Agricultural University for the excellent facilities during his $\mathrm{PhD}$ study.

\section{REFERENCES}

[1] Afzaal, Z., M. A. Kalhoro, M. A. Buzdar, S.Tariq, M. Shafi, A. Nadeem, S. Imran, F. Saeed, M. Sohail, R. Hasan, A. Haroon, H. Shah and I. Ahmed. 2018. Carapace length-weight and width-weight relationship of Portunus pelagicus (Linnaeus, 1758) in Pakistan waters northern Arabian Sea. Indian Journal of Geo Marine Sciences 47 (4): 890-896.

[2] Araújo, M. S. C. and J. J. P. R. Lira, 2012. Condition factor and carapace width versus wet weight relationships in the swimming crab Callinectes danae Smith 1869 (Decapoda: Portunidae) at the Santa Cruz Channel, Pernambuco State, Brazil. Nauplius 20(1): 41-50.

[3] Atar, H. H. and S. Secer, 2003. Width/length-weight relationships of the blue crab (Callinectes sapidus Rathbun 1896) population living in Beymelek Lagoon Lake. Turkish Journal of Veteriner and Animal Sciences 27: 443-447.

[4] Bastami, A. A., M. Najafian and M. Hosseini, 2012. The distribution of the barnacle epizoites, Chelonibita patula (Ranzani) on blue swimmer crab, Portunus pelagicus (Linnaeus, 1758). World Applied Sciences Journal 20(2): 236-240.

[5] de Lestang, S., N. G. Hall and I.bC. Potter, 2003. Reproductive biology of the blue swimmer crab (Portunus pelagicus, Decapoda: Portunidae) in five bodies of water on the West Coast of Australia. Fishery Bulletin 101: 745-757.

[6] Dineshbabu, A. P., Shridhara, B. and Muniyappa, Y., 2008. Biology and exploitation of the blue swimmer crab, Portunus pelagicus (Linnaeus, 1758), from South Karnataka Coast, India. Indian Journal of Fisheries, 55(3), 215-220.

[7] Dubey, S. K., D. C. Chakraborty, C. Bhattacharya and A. Choudhury, 2014. Allometric relationships of red ghost crab Ocypode macrocera (H. MilneEdwards, 1852) in Sundarbans mangrove eco-region, India. World Journal of Fish and Marine Sciences 6(2): $176-181$.

[8] Edritanti, Q., A. Farajallah and Y. Wardiatno, 2016. Reproductive biology of ovigerous female Emerita emeritus (Crustacea, Decapoda) in Bengkulu coastal waters, Indonesia: egg production and reproductive output. Croatian Journal of Fisheries 74(3): 103-109.

[9] Ernawati, T., 2013. Population dynamics and stock assessment of blue swimmer crab (Portunus pelagicus Linnaeus) resource in Pati and adjacent waters. Master Thesis. Bogor Agricultural University. Bogor, Indonesia. 80 p. (in Indonesian).

[10] Froese, R., 2006. Cube law, condition factor and weight-length relationships: history, meta analysis and recommendation. Journal of Applied Ichthyology 22: 241-253.

[11] Gayanilo, F. C. Jr., P. Sparre and D. Pauly, 2005. FAO-ICLARM stock assessment tools (FISAT II). Revised Version. FAO Computerized. Information Series (Fisheries), Rome, 8, 168 pp.

[12] Hamid, A., 2015. Habitat, reproductive biology and population dynamics of blue swimming crab (Portunus pelagicus Linnaeus 1758) as the basis for management in the Lasongko Bay, Southeast Sulawesi. Dissertation. Bogor Agricultural University. Bogor, Indonesia. 164 p. (in Indonesian).

[13] Hamid, A. and Y. Wardiatno, 2015. Population dynamics of the blue swimming crab (Portunus pelagicus Linnaeus, 1758) in Lasongko Bay, Central Buton, Indonesia. AACL Bioflux 8(5): 729-739.

[14] Hamid, A., Wardiatno, Y., Lumban Batu, D. T. F. and Riani, E., 2015. Fecundity and gonad maturity stages of ovigerous female blue swimming crab (Portunus pelagicus) in Lasongko Bay, Southeast Sulawesi. Bawal, 7(1), 43-50. (in Indonesian).

[15] Hamid, A., Y. Wardiatno, D. T. F. Lumban Batu and E. Riani, 2016. Distribution, body size, and eggs of ovigerous swimming crab (Portunus pelagicus Linnaeus 1758) at various habitats in Lasongko Bay, Central Buton, Indonesia. International Journal of Aquatic Biology 4(2): 108-116.

[16] Hamid, A., D. T. F. Lumban Batu, E. Riani and Y. Wardiatno, 2016. Reproductive biology of blue swimming crab (Portunus pelagicus Linnaeus, 1758) in Lasongko Bay, Southeast Sulawesi-Indonesia. AACL Bioflux 9(5): 1053-1066.

[17] Hamid, A., Y. Wardiatno, D. T. F. Lumban Batu and E. Riani, 2016. Stock status and fisheries exploitation of blue swimming crab Portunus pelagicus (Linnaeus 1758) in Lasongko Bay, Central Buton, Indonesia. Asian Fisheries Science 29(4): 206-219.

[18] Hartnoll, R. G., 1978. The determination of relative growth in crustacea. Crustaceana 34(3): 281-293.

[19] Huang, J. R., C. L. Brown and T. B Yang, 2011. Spatio-temporal patterns of crab fisheries in the main bays of Guangdong Province, China. Iranian Journal of Fisheries Science 10(3): 425-436.

[20] Ihsan, E. S. Wiyono, S. H. Wisudo and J. Haluan, 2014. A study of biological potential and sustainability of swimming crab in the waters of Pangkep Regency South Sulawesi Province. International Journal of Basic and Applied Sciences 16(1): 351-363.

[21] Josileen, J., 2011. Morphometrics and length-weight relationships in the blue swimmer crab, Portunus pelagicus (Linnaeus, 1758) (Decapoda, Brachyura) from the Mandapam Coast, India. Crustaceana 84(14): 1665-1681.

[22] Juwana, S., 1997. Review of research development of blue swimming crab (Portunus pelagicus) culture. Oseana, 22(4), 1-12. (in Indonesian).

[23] Kamrani, E., A. N. Sabili and M. Yahyavi, 2010. Stock assessment and reproductive biology of the blue swimming crab, Portunus pelagicus in Bandar Abbas Coastal waters, Northern Persian Gulf. Journal of Persian Gulf 1(2): 11-22.

[24] Kunsook, C., N. Gajaseni and N. Paphavasit, 2014. A stock assessment of the blue swimming crab Portunus pelagicus (Linnaeus, 1758) for sustainable management in Kung Krabaen Bay, Gulf of Thailand. Tropical Life Sciences Research 25(1): 41-59.

[25] Lai, J. C. Y., P. K. L Ng and P. J. F. Davie, 2010. A revision of the Portunus pelagicus (Linnaeus, 1758) species complex (Crustacea: Brachyura: Portunidae), with the recognition of four species. The Raffles Bulletin of Zoology 58(2): 199-237.

[26] LeCren, E. D., 1951. The length-weight relationships and seasonal cycle in gonad weight and condition in the Perch (Perca fluviatilis). Journal of Animal Ecology 20(2): 201-219.

[27] Mehanna, S. F., S. Khvorov, M. Al-Sinawy, Y. S. Al-Nadabi and M. N. Al-Mosharafi, 2013. Stock assessment of the blue swimmer crab Portunus pelagicus (Linnaeus, 1766) from the Oman Coastal waters. International Journal of Fisheries and Aquatic Sciences 2(1): 1-8.

[28] Moslen, M and C. A. Miebaka, 2018. Condition factor and length-weight relationship of two estuarine shell fish (Callinectes sp and Penaeus sp) from the Niger Delta, Nigeria. International Journal of Fisheries and Aquatic Sciences 6 (1): 188-194. 
[29] Myla, S. C., V. B. Tirumani and R. C. G. Paturi, 2017. Body weight, carapace length and width relationship and condition factor of the mud crab Scylla serrata (Forskal) in mangrove ecosystem. Notulae Scientia Biologicae 9(3): 338-343.

[30] Ningrum, V. P., A. Ghofar and C. Ain, 2015. Biological aspects of blue swimmer crab (Portunus pelagicus) in Betahwalang waters and around. Jurnal Saintek Perikanan 11(1): 62-71 (in Indonesian).

[31] Noori, A., P. Moghaddam, E. Kamrani, A. Akbarzadeh, B. K. Neitali and M. A. A. Pinheiro, 2015. Condition factor and carapace width versus wet weight relationships in the blue swimming crab Portunus segnis. Animal Biology 65: 87- 99.

[32] Nugraha, 2011. Morphometry, growth, and maturity gonad stage of blue swimming crab (Portunus pelagicus) in the Dendang waters East Belitung Regency, Bangka Belitung. Thesis. Faculty of Fisheries and Marine Sciences, Diponegoro University. Semarang. 17 p. (in Indonesian).

[33] Omolara, L. A. A. and B. Barakat, 2009. The biology of the smooth swim crab, Portunus validus (Herklots) of Lago`s coast, Nigeria. European Journal of Scientific Research 30(3): 402-408

[34] Pramithasari F. A., N. A. Butet and Y. Wardiatno, 2017. Variation in morphometric characters in four sand crab (Albunea symmysta) populations collected from Sumatra and Java Island, Indonesia. Tropical Life Sciences Research 28(1): 103-115.

[35] Rasheed, S. and J. Mustaquim, 2014. Relative growth and morphometric measurements as an index for estimating meat yield of two edible crabs Portunus pelagicus and P. sanguinolentus from the coastal waters of Pakistan. International Journal of Innovation and Applied Studies 9(4): 1994-2009.

[36] Razek, A. F. A., S. M. Taha and A. A. Ameran, 2006. Population biology of the edible crab Portunus pelagicus (Linnaeus) from Bardawil Lagoon, Northern Sinai, Egypt. Egyptian Journal of Aquatic Research 32(1): 401-418.

[37] Safaie, M., J. Pazooki, B. Kiabi and M. R. Shokri, 2013. Reproductive biology of blue swimming crab, Portunus segnis (Forskal, 1775) in coastal waters of Persian Gulf and Oman Sea, Iran. Iranian Journal of Fisheries Science 12(2): 430-444.

[38] Sawusdee, A. and A. Songrak, 2009. Population dynamics and stock assessment of blue swimming crab (Portunus pelagicus Linnaeus, 1758) in the coastal area of Trang Province, Thailand. Walailak Journal of Science and Technology 6(2): 189-202.

[39] Sentosa, A. A. and A. R. Syam, 2011. Temporal distribution of condition factor of the mud crab (Scylla serrata) in Mayangan coastal waters, Subang Regency, West Java. Jurnal Perikanan 13(1): 35-43 (in Indonesian).

[40] Sukumaran, K. K. and B. Neelakantan, 1996. Relative growth and sexual maturity in the marine crabs, Portunus (Portunus) sanguinolentus (Herbst) and Portunus (Portunus) pelagicus (Linnaeus) along the Southwest Coast of India. Indian Journal of Fisheries 43(3): $215-223$.

[41] Sunarto, D. Soedharma, E. Riani and S. Martasuganda, 2010. Length-weight and width with body weight relationships and condition factor of population crab (Portunus pelagicus) of males and females in coastal waters of Brebes. Jurnal Akuatika 1(1): 83-92 (in Indonesian).

[42] Steel, R. G. D. and J. H. Torrie, 1980. Principles and procedures of statistics. Second Edition. McGraw-Hill Book Co. New York, 622 p.

[43] Wardiatno, Y. and A. Tamaki, 2001. Bivariate discriminant analysis for the identification of Nihonotrypaea japonica and N. harmandi (Decapoda: Thalassinidea: Callianassidae). Journal of Crustacean Biology 21(4): 1042-1048.

[44] Zairion, M. Boer, Y. Wardiatno, and A. Fahrudin, 2014. Composition and size of blue swimming crab (Portunus pelagicus) caught at several bathymetri stratification in East Lampung waters. Jurnal Penelitian Perikanan Indonesia 20(4): 199-206 (in Indonesian).

[45] Zairion, Y. Wardiatno, M. Boer and A. Fahrudin, 2015. Reproductive biology of the blue swimming crab Portunus pelagicus (Brachyura: Portunidae) in East Lampung waters, Indonesia: fecundity and reproductive potential. Tropical Life Sciences Research 26(1): 67-85. 